\title{
Properties of Phage-receptor Lipopolysaccharide from Pseudomonas morsprunorum
}

\author{
By A. V. QUIRK, A. SLETTEN* AND R. C. HIGNETT \\ East Malling Research Station, Maidstone, Kent ME $196 \mathrm{BJ}$
}

(Received 20 April 1976; revised 27 May 1976)

\begin{abstract}
SUMMARY
Lipopolysaccharide (LPS) of Pseudomonas morsprunorum was extracted with hot phenol and purified by repeated centrifuging followed by either block electrophoresis or gel filtration. LPS from a virulent isolate exhibited specific phage inactivation ( $\left.\mathrm{PI}_{50}=0.05 \mu \mathrm{g} \mathrm{LPS} \mathrm{ml}{ }^{-1}\right)$, whereas LPS from an avirulent phageresistant mutant did not. LPS was considered pure when a single band was detected following sodium dodecyl sulphate-cellulose acetate electrophoresis $(\mathrm{pH} 7 \cdot 4)$. It was not phytotoxic when inoculated into cherry leaves at concentrations up to $\mathrm{I} \mathrm{mg} \mathrm{ml}^{-1}$, but produced weak chlorosis in bean and tobacco at $2 \mathrm{mg} \mathrm{ml}^{-1}$ : no visible symptoms appeared after treatment with lower concentrations. The chemical composition of the LPS was partly determined.
\end{abstract}

\section{INTRODUCTION}

There is a strong correlation between phage sensitivity and host specificity in the English isolates of Pseudomonas morsprunorum, the cause of cherry canker (Crosse \& Garrett, 1970). Isolates from cherry are sensitive to A7 and related phages (Crosse \& Garrett, 1963) and infect cherry trees (Prunus avium) through the leaf scars. Almost all plum strains are insensitive to these phages and are non-virulent through cherry leaf scars. Plum strains adsorb phage $\mathrm{A} 7$ as readily as do cherry strains, suggesting that phage-receptor material in the bacterial wall is not involved in the host specificity of the strains (Garrett, Crosse \& Sletten, 1974).

Cherry-strain mutants resistant to these phages show marked attenuation of virulence. Their resistance is due to an inability to adsorb the phage, indicating a change in the receptor-site structure (Garrett et al., 1974). Hence, receptor-site material may determine the virulence of $P$. morsprunorum as plum and cherry isolates adsorb the phage and are both virulent on their respective hosts.

Lipopolysaccharide (LPS) of Gram-negative bacterial walls has frequently been reported as phage-receptor material (e.g. Jazwinski, Lindberg \& Kornberg, 1975) and also as an endotoxin (e.g. Hawiger, Hawiger \& Timmon, I975). In view of this, lipopolysaccharide was extracted from $P$. morsprunorum to investigate its role in pathogenicity and as receptorsite material for phage $\mathrm{A}_{7}$ and related phages.

\section{METHODS}

Growth of bacteria. Cultures of cherry isolate C28, plum isolate D5 and phage-resistant mutant $\mathrm{C}_{46 \mathrm{MD}}$ of $P$. morsprunorum were grown in 51 cultures of nutrient glycerol broth

- Present address: Norwegian Plant Protection Institute, I432 AS-NLH, Norway. 
[containing $0.8 \%$ nutrient broth (Difco), $0.3 \%$ yeast extract (Difco), $2 \%$ (w/v) glycerol; $\mathrm{pH} 7$ 7] to which one drop of antifoam (polypropylene glycol 2000; Shell Research, Sittingbourne, Kent) was added before autoclaving. The cultures were stirred and aerated at $18{ }^{\circ} \mathrm{C}$. Air was supplied at $500 \mathrm{~cm}^{3} \mathrm{~min}^{-1}$ via a sintered-glass gas distribution tube (porosity 3). The purity of the cultures was tested by the Gram-stain method and by subculturing on nutrient sucrose agar (NSA; Crosse, 1959). The optimum temperature for growth of c28 is normally $25^{\circ} \mathrm{C}$ but when grown in broth with efficient aeration and stirring at this temperature, cells grew to 4 to 5 times their normal length. These cells quickly reverted to the normal size when aeration was reduced and were not elongated when grown at $18{ }^{\circ} \mathrm{C}$. Cells were harvested at the late-exponential phase using a continuous-flow centrifuge at $4{ }^{\circ} \mathrm{C}$, and washed twice with cold distilled water by centrifugation. The bacterial pellet was suspended in a small volume of cold distilled water; the suspension was poured into Io vols cold acetone $\left(-10^{\circ} \mathrm{C}\right)$ and then centrifuged. The pellet was dried in a vacuum over phosphorus pentoxide at room temperature. Approximately $4.5 \mathrm{~g}$ acetone-dried material was obtained from each 51 culture.

Preparation and purification of lipopolysaccharide. LPS was obtained from the acetonedried cells by the hot phenol method (Westphal \& Jann, 1965). The combined aqueous extracts were exhaustively dialysed against distilled water at $4{ }^{\circ} \mathrm{C}$. The non-dialysable material was centrifuged ( $100000 \mathrm{~g}$ at $4{ }^{\circ} \mathrm{C}$ for $2.5 \mathrm{~h}$ ), washed in the same volume of cold distilled water and recentrifuged. The pellet was resuspended in a minimal volume of water, extracted three times with equal volumes of ether and then freeze-dried.

This crude LPS was further purified by block electrophoresis in 0.1 M-phosphate buffer $(\mathrm{pH} 7 \cdot 4)$ with $\mathrm{I} \%$ agarose as support $(\mathrm{I} 5 \times 8 \times \mathrm{I} \mathrm{cm})$. A suspension of LPS $\left(5 \mathrm{mg} \mathrm{ml}^{-1}\right)$ in the same buffer was deposited in a central slot $(0.7 \times 7.0 \times 0.9 \mathrm{~cm})$ in the agarose support. Electrophoresis conditions were $100 \mathrm{~V}$ and $20 \mathrm{~mA}$ for $3.5 \mathrm{~h}$ at room temperature. Purified LPS was recovered from the slot. Alternatively, the LPS was dissolved in $0.0 \mathrm{I} M-\mathrm{NH}_{4} \mathrm{HCO}_{3}$ (Romanowska, 1970) and purified by gel filtration on an agarose column (I \% agarose, granulated $60 \mathrm{mesh}$ ), the fast-running material being collected. The LPS preparation was then saturated with urea, extracted three times with equal volumes of ether and the aqueous phase was exhaustively dialysed against distilled water before being freeze-dried.

Samples of LPS were taken during the purification procedure, mixed with I vol. $0.5 \%$ $(\mathrm{w} / \mathrm{v})$ bovine serum albumin, dried on to formvar/carbon coated electron microscope grids and negatively stained with $4 \%(\mathrm{w} / \mathrm{v})$ sodium phosphotungstate. Other samples were tested for chemical purity using cellulose acetate electrophoresis. These were pre-incubated with phosphate buffer (as above) containing I \% (w/v) sodium dodecyl sulphate (SDS) for I h at $37^{\circ} \mathrm{C}$ before electrophoresis ( $200 \mathrm{~V}, 8 \mathrm{~min}$ ) with the same buffer. LPS was detected, after periodate oxidation, with Schiff's reagent. Lipophilic bands were detected with $0.1 \%$ aqueous Rhodamine B.

Chemical analysis of $\mathrm{C} 28$ lipopolysaccharide. LPS $(2 \mathrm{mg}$ ) was dissolved in $0.3 \mathrm{ml} 0.05$ $\mathrm{M}-\mathrm{KOH}$ and hydrolysed for $\mathrm{I} \mathrm{h}$ at $50^{\circ} \mathrm{C}$. The solution was acidified $(6 \mathrm{M}-\mathrm{HCl} ; 0.15 \mathrm{ml})$, extracted with ether $(6 \times 0.3 \mathrm{ml})$, hydrolysed at $100^{\circ} \mathrm{C}$ for $20 \mathrm{~min}$, and then extracted with ether again. The ether extracts were dried separately on tared aluminium foil pans and weighed on a Sauter torsion balance. The aqueous phase was dried by rotary evaporation at $50{ }^{\circ} \mathrm{C}$, redissolved in distilled water and dried. After repeating this process, the solid was dissolved in distilled water. Samples were removed and stored in $10 \%(\mathrm{v} / \mathrm{v})$ isopropanol for sugar estimations. Sugars, separated by paper chromatography (n-butanol/pyridine/ water; 6:4:3, by vol.), were detected using $p$-aminobenzoic acid (Saini, I966) and estimated by densitometry. Individual sample and standard reference sugar spots were scanned on a 
Joyce Loebl Chromoscan using a $430 \mathrm{~nm}$ transmission filter. Concentrations of glucose and rhamnose between 0 and $7.5 \mathrm{~mm}$ produced a linear response and this was used to calculate the concentrations of these compounds in the samples.

The remaining hydrolysate was transferred to a hydrolysis tube and dried. Hydrochloric acid $(6 \mathrm{M} ; 0.2 \mathrm{ml}$ ) was added, and the tube was flushed with carbon dioxide, sealed and heated to $105^{\circ} \mathrm{C}$ for 18 to $24 \mathrm{~h}$. The solution was removed, diluted and dried three times by rotary evaporation at $50{ }^{\circ} \mathrm{C}$, and the dried sample was dissolved in $10 \%$ isopropanol. Acid-free samples $(5 \mu \mathrm{l})$ and standard leucine solutions (up to $5 \mathrm{mM}$ ) were spotted on to strips of chromatography paper (Whatman no. I). The paper was dipped in acetone containing $\mathrm{I} \%$ ninhydrin and $\mathrm{I} \%$ pyridine and then heated at $105{ }^{\circ} \mathrm{C}$ for $3 \mathrm{~min}$. The resulting spots were scanned using white light on the Chromoscan and the total amino acid concentrations in the samples were calculated as described above.

Inorganic phosphate was determined by the method of Murphy \& Riley (1962) using acid-hydrolysed LPS. Samples (I $\mathrm{mg}$ ) were dried, moistened with concentrated sulphuric acid, and sufficient $29 \%(\mathrm{w} / \mathrm{v})$ hydrogen peroxide was added to give a clear solution.

2-Keto-3-deoxyoctonic acid (KDO) was determined by the method of Weissbach \& Hurwitz (1959), as modified by Osborn (1963), using intact LPS and samples taken after dilute acid hydrolysis, and a standard KDO solution.

The glucose content of partially acid-hydrolysed LPS was confirmed using the glucose blood oxidase kit (Sigma).

The water loss from LPS on drying at $20^{\circ} \mathrm{C}$ under vacuum in the presence of phosphorus pentoxide was determined gravimetrically.

Phage experiments. Phage-sensitivity and phage-adsorption tests were done using procedures and media described by Crosse \& Garrett (I963) and Garrett et al. (1974). Phage-receptor material was diluted in distilled water and a sample $(0.2 \mathrm{ml})$ was thoroughly mixed with an equal volume of phage preparation at $\mathrm{Io}^{4}$ plaque-forming units (p.f.u.) $\mathrm{ml}^{\mathbf{l}}$. The mixture was incubated for $\mathrm{I} h$ at room temperature and shaken occasionally. Samples (.. $\mathrm{I} \mathrm{ml)}$ were taken diluted in phage broth and $0.02 \mathrm{ml}$ portions were plated (Miles \& Misra, 1938), in triplicate, on the appropriate bacterial lawn (Crosse \& Garrett, 1963). Plaques were counted after incubation for between 8 and $16 \mathrm{~h}$ at $25^{\circ} \mathrm{C}$.

Phytotoxicity. Purified LPS was injected at various concentrations into the leaves of rapidly growing tobacco (Nicotiana tabacum, cv. White Burley) and bean (Phaseolus vulgaris cv. Canadian Wonder) plants using a no. 20 hypodermic needle. LPS was also vacuum infiltrated into partly expanded leaves of cherry seedlings (Prunus avium) and beans by the method of Hignett (1975). All plants were grown under a $16 \mathrm{~h}$ photo-period (minimum visible radiation approx. $170 \mathrm{~J} \mathrm{~cm}^{-2}$ ).

Protection against the hypersensitive response. The hypersensitive response of a plant following inoculation with incompatible bacteria is characterized by localized necrosis (Klement \& Goodman, 1967). This reaction can be prevented in tobacco by prior introduction of bacterial wall material (Sequeira, Aist \& Ainslie, 1972). To determine whether LPS could induce this protective response, tobacco leaves were injected, as above, with a solution of LPS $\left(0 \cdot 7 \mathrm{mg} \mathrm{ml}^{-1}\right)$. After $24 \mathrm{~h}$ the same leaf area was injected with a suspension $\left(\mathrm{IO}^{8}\right.$ cells $\left.\mathrm{ml}^{-1}\right)$ of $P$. morsprunorum in distilled water. 
Table 1. Chemical composition of $\mathrm{C} 28$ LPS

\begin{tabular}{|c|c|c|}
\hline Constituent & $\begin{array}{l}\text { Content } \\
\text { (\% by wt) }\end{array}$ & \\
\hline Phosphorus & $I \cdot 2$ & \\
\hline $\begin{array}{l}\text { Alkali-labile lipid } \\
\text { Acid-labile lipid }\end{array}$ & $\left.\begin{array}{r}2 \cdot 5 \\
22 \cdot 5\end{array}\right\}$ & $25 \%$ total lipid \\
\hline $\begin{array}{l}\text { Rhamnose } \\
\text { Glucose } \\
\text { KDO }\end{array}$ & $\left.\begin{array}{r}20.2 \\
5.5 \\
1.6\end{array}\right\}$ & $27 \cdot 3 \%$ sugar \\
\hline $\begin{array}{l}\text { Leucine equivalents } \\
\mathrm{H}_{2} \mathrm{O}\end{array}$ & $\begin{array}{r}2 \cdot 6 \\
15 \cdot 0\end{array}$ & \\
\hline Total & $71 \cdot 1$ & \\
\hline
\end{tabular}

RESULTS

Analysis of lipopolysaccharide

Agarose block electrophoresis or gel filtration removed contaminating nucleic acid from the LPS, as shown by the loss of the u.v. absorption shoulder at $260 \mathrm{~nm}$. Samples analysed by cellulose acetate-SDS electrophoresis after these treatments gave rise to two lipophilic bands, in addition to the LPS band. These bands were absent after treatment with saturated urea and ether extraction, when only a single band of LPS was detected: the sample was therefore considered to be pure. Lipopolysaccharide from isolate $\mathbf{C 2} 8$ was not recovered from the SDS complex by simple dialysis, nor by prior treatment with urea $(6 \mathrm{M})$ or saturated salt solutions. Electron micrographs of LPS, obtained after repeated centrifuging, showed a dense network of threads and spheres approximately $7 \mathrm{~nm}$ in diameter. After gel chromatography or block electrophoresis, the LPS was composed entirely of spherical particles, between 2 and $10 \mathrm{~nm}$ in diameter, but exhibiting a discontinuous size distribution. After the saturated urea/ether treatment, electron micrographs showed mainly spheres together with some plate-like structures.

The chemical composition of purified LPS from $P$. morsprunorum isolate $\mathbf{C 2} 8$ is shown in Table I. Elemental analysis of the LPS showed $36.7 \%$ carbon, $7 \cdot 3 \%$ hydrogen and I.6\% nitrogen. Desiccated LPS rapidly increased in weight (by approximately $15 \%$ ) when the sample was exposed to the air. Heptose was not detected by the cysteine-sulphuric acid method (Dische, 1953), as modified by Wright \& Rebers (1972), or with aniline hydrogen phthalate after separating the sugars by paper chromatography (Hofstad, 1974). The same LPS composition was obtained when the bacteria were grown slowly in 0.5 or 2.51 batches in rotating flasks.

However, some inconsistency was encountered during chemical analysis. LPS was extracted and purified from $P$. morsprunorum isolate $\mathrm{c} 28$ several times over a period of 2 years from periodically subcultured stock cultures (stored at $4^{\circ} \mathrm{C}$ ). Although pathogenicity and colony morphology (on NSA) of the subcultures and the antiphage activity of the derived LPS remained the same, the LPS sugar ratio (glucose:rhamnose) changed from approximately I:I to I:4. Crude LPS purified by electrophoresis after 2 years in freezedried suspension and LPS freshly prepared from bacteria derived from a culture of $\mathrm{C} 28$ which had been stored at $4{ }^{\circ} \mathrm{C}$ both had approximately the same original sugar ratio (I: $:$ ). In contrast, LPS prepared at the same time from later subcultures of $\mathbf{C 2} 8$ had sugar ratios of about I:4, as did LPS prepared from a broth culture grown at $25^{\circ} \mathrm{C}$ without aeration. Thus changes in cultural conditions did not affect the composition of the LPS. The evidence 


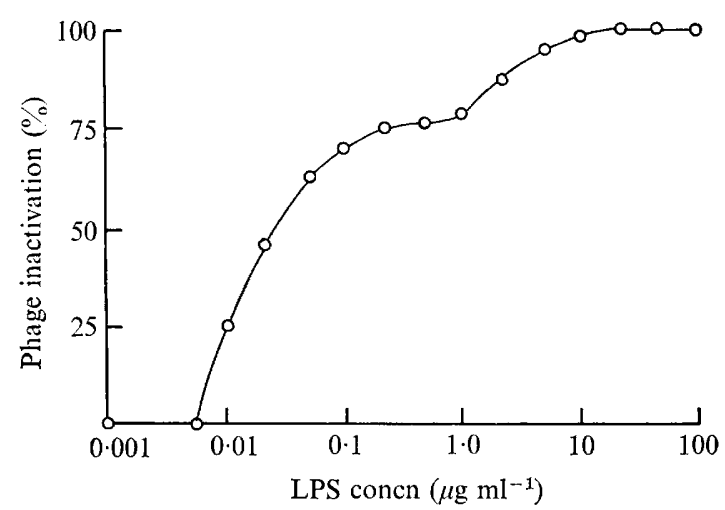

Fig. I. Inactivation of phage $\mathrm{A}_{7}$ by purified lipopolysaccharide extracted from Pseudomonas morsprunorum c28. Mixtures of LPS and phage ( $\mathrm{IO}^{4}$ p.f.u. $\mathrm{ml}^{-1}$ ) were incubated at room temperature for $\mathrm{I} \mathrm{h}$ prior to sampling, diluting and plating on a $\mathrm{C2} 8$ lawn. Phage inactivation was measured as a percentage decrease in plaque-forming units.

Table 2. Specific phage inactivation by lipopolysaccharide isolated from Pseudomonas morsprunorum

Adsorption and inactivation were considered positive when the number of plaque-forming units decreased by $50 \%$. Lysis was considered positive when phage, applied directly on to the bacterial lawn, produced plaques after incubation at $25^{\circ} \mathrm{C}$. $\mathrm{C} 28$ was used as an indicator for all phages except phage $\mathrm{C} 6$ for which $P$. phaseolicola 606 was used.

Phage

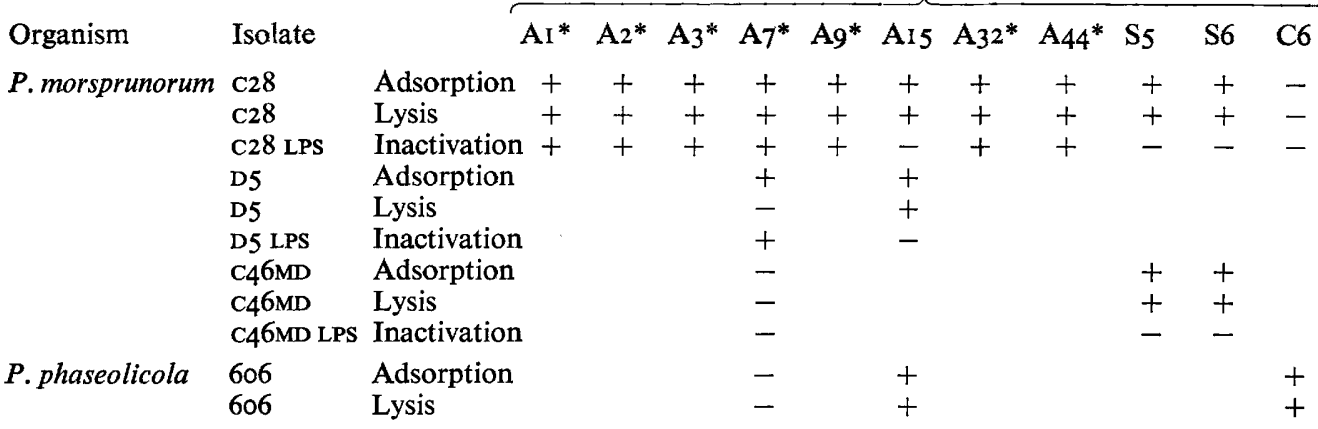

* Phages that show a degree of specificity for $P$. morsprunorum cherry strains.

of heterogeneity suggests that selection of a different population had occurred during the period of storage at $4{ }^{\circ} \mathrm{C}$ or during subculture.

\section{Phage inactivation}

Crude C28 or D5 LPS, obtained after repeated centrifuging, produced a $50 \%$ decrease in phage A7 plaque formation $\left(\mathrm{PI}_{50}\right)$ when used at $0.25 \mu \mathrm{g} \mathrm{ml}^{-1}$. After purification by block electrophoresis or by gel chromatography, $\mathrm{PI}_{50}$ was reduced to $0.05 \mu \mathrm{g} \mathrm{ml}^{-1}$ (Fig. I). A range of phages having various degrees of specificity for $P$. morsprunorum was tested against LPS. Only those of the $\mathrm{A}_{7}$ group, which show specificity for cherry isolates, were inactivated (Table 2). Phage C6, a phage specific for P. phaseolicola, was neither inactivated by LPS extracted from $\mathrm{C} 28$ or D5 nor adsorbed by the intact bacteria. Phage AI 5 was adsorbed by C28 and D5 but was not inactivated by the LPS from either isolate. Similarly, phages $\mathrm{S}_{5}$ 
and $\mathrm{S} 6$ were adsorbed by $\mathrm{C} 28$ but were not inactivated by the C28 LPS. Neither the phageresistant mutant $\mathrm{C}_{46 \mathrm{MD}}$ nor its LPS reacted with phage A7. Phages which were not inactivated by LPS at $0.05 \mu \mathrm{g} \mathrm{ml}^{-1}$ were tested against LPS concentrations at up to $5 \mathrm{mg} \mathrm{ml}^{-1}$, but these were without effect.

Electron micrographs obtained after incubating C28 LPS with phage A7 did not show the spheres which were characteristic of the LPS. The spheres did not disappear after incubation with phage AI5.

\section{Phytotoxicity and hypersensitivity}

Purified LPS injected into bean and tobacco leaves at $2 \mathrm{mg} \mathrm{ml}^{-1}$ produced weak chlorosis after several days, the reaction being visibly similar to symptoms produced by injecting a suspension of saprophytic bacteria. No effects were observed at lower concentrations. LPS produced no visible effects when infiltrated into cherry (at up to I $\mathrm{mg} \mathrm{ml}^{-1}$ ) or bean leaves (at up to $0.05 \mathrm{mg} \mathrm{m}^{-1}$ ). Pre-injection of tobacco leaves with LPS failed to prevent the hypersensitive response when they were subsequently inoculated with the live pathogen.

\section{DISCUSSION}

Analysis of C28 LPS accounted for about $70 \%$ of the macromolecule, as do published analyses of LPS extracted from other Gram-negative bacteria (e.g. Chester, Gray \& Wilkinson, 1972).

The phage-inactivation tests indicate that only LPS from a virulent isolate of $P$. morsprunorum is specific receptor-site material for phage $\mathrm{A}_{7}$ and related phages. Phages $\mathrm{A}_{15}$, S5 and S6, which adsorb to the cherry isolate as readily as do the A7 group, are not inactivated by LPS, indicating that other wall material must be responsible for their adsorption.

Lipomucopolysaccharide isolated from $P$. lachrymans (Keen \& Williams, 197I) produced water-soaking when injected into cucumber leaves. The preparation contained $12 \%$ protein and when treated with phenol some of this protein was lost; simultaneous loss of phytotoxicity was not reported. Keen \& Long (1972) reported the presence of a protein-lipopolysaccharide complex in cultures of the fungus Verticillium albo-atrum which proved toxic to cotton leaves. In both of these cases, the toxic LPS was complexed with protein, which contrasts with the purified non-phytotoxic LPS that is the subject of this paper.

The LPS from $P$. morsprunorum was rigorously purified before phytotoxicity tests for two reasons. First, some phytotoxins are extremely potent, e.g. victorin (Scheffer \& Pringle, 1964), and minor contamination with such materials may have falsely indicated phytotoxic properties for the LPS. Secondly, any contaminants may have interfered with the action of the LPS at postulated target sites within the plant tissues. In tests using plant tissues the purified LPS showed no biological activity; it neither induced a toxic reaction nor prevented hypersensitivity. However, it would be premature to conclude from this that it has no role in pathogenicity. The LPS from the less virulent, phage-resistant strain of $P$. morsprunorum did not inactivate phage $\mathrm{A}_{7}$ and was clearly different from that of the wild-type strain. Further, an LPS-protein complex isolated from a virulent strain of $P$. morsprunorum has been shown to be phytotoxic (Hignett \& Quirk, 1975). These observations suggest that LPS may be active as a virulence determinant when linked with other materials.

A.S. was financed by a NATO Science Fellowship granted by the Royal Norwegian Council for Scientific and Industrial Research and a grant from the Norwegian Agricultural Research Council. A.V.Q. wishes to thank the ARC for a postgraduate studentship. 
The authors thank Miss M. M. Fuller for the electron microscopy, Miss C. M. E. Garrett for providing the stock cultures, Dr S. G. Wilkinson, University of Hull, for the gift of the KDO and Dr J. E. Crosse for his advice and interest in their work.

\section{REFERENCES}

Chester, I. R., Gray, G. W. \& Wilkinson, S. G. (1972). Further studies of the chemical composition of the lipopolysaccharide of Pseudomonas aeruginosa. Biochemical Journal 126, 395-407.

Crosse, J. E. (1959). Bacterial canker of stone-fruits. IV. Investigation of a method for measuring the inoculum potential of cherry trees. Annals of Applied Biology 47, 306-317.

Crosse, J. E. \& GARReTt, C. M. E. (1963). Studies on the bacteriophagy of Pseudomonas morsprunorum, Ps. syringae and related organisms. Journal of Applied Bacteriology 26, I 59-177.

Crosse, J. E. \& GARReTt, C. M. E. (1970). Pathogenicity of Pseudomonas morsprunorum in relation to host specificity. Journal of General Microbiology 62, 315-327.

DischE, Z. (1953). Quantitative and qualitative determination of heptoses. Journal of Biological Chemistry 204, $983-997$.

GarretT, C. M. E., Crosse, J. E. \& Sletten, A. (1974). Relations between phage sensitivity and virulence in Pseudomonas morsprunorum. Journal of General Microbiology 80, 475-483.

Hawiger, J., Hawiger, G. \& Timmon, S. (1975). Endotoxin-sensitive membrane components of human platelets. Nature, London 256, I25-I 26.

HignetT, R. C. (1975). Vacuum infiltration of plant leaves in situ. Laboratory Practice 24, 586.

HignetT, R. C. \& QUIRK, A. V. (1975). Phytotoxins of plant pathogenic pseudomonads. Ioth International Congress FEBS, Paris. Abstract no. 1425. Paris: Société de Chimie Biologique.

HofSTAD, T. J. (1974). Distribution of 2-keto-3-deoxyoctonate in Bacteroidaceae. Journal of General Microbiology 85, 314-320.

JAZWINSKI, S. M., LINDBERG, A. A. \& KorNBERG, A. (1975). The lipopolysaccharide receptor for bacteriophage $\phi \mathrm{X}_{1} 74$ and Si3. Virology 66, 268-282.

KeEN, N. T. \& LONG, M. (1972). Isolation of a protein-lipopolysaccharide complex from Verticillium albuatrum. Physiological Plant Pathology 2, 307-315.

Keen, N. T. \& Williams, P. H. (197I). Chemical and biological properties of a lipomucopolysaccharide from Pseudomonas lachrymans. Physiological Plant Pathology I, 247-264.

Klement, Z. \& GoOdman, R. N. (1967). The hypersensitive reaction to infection by bacterial plant pathogens. Annual Review of Phytopathology 5, I7-44.

Miles, A. A. \& MisRa, S. S. (1938). The estimation of the bactericidal power of the blood. Journal of Hygiene 38, 732-742.

MURPHY, J. \& RILEY, J. P. (I962). A modified single solution method for the determination of phosphate in natural waters. Analytica chimica acta 27, 3 I-36.

OsBoRN, M. J. (1963). Studies on the Gram-negative cell wall. I. Evidence for the role of 2-keto-3-deoxy* octonate in the lipopolysaccharide of Salmonella typhimurium. Proceedings of the National Academy of Sciences of the United States of America 50, 499-506.

RomANOWSKA, E. (1970). Sepharose gel filtration method of purification of lipopolysaccharides. Analytical Biochemistry 33, 383-389.

SAINI, A. S. (1966). Technical improvements in paper chromatography of sugars: method of sample desalting and sensitive staining reagent. Journal of Chromatography 24, 484-486.

SCHEFfer, R. P. \& Pringle, R. B. (1964). Uptake of Helminthosporium victoriae toxin by oat tissue. Phytopathology 54, 832-835

SequeIRA, L., AIST, S. \& AINSLIE, V. (1972). Prevention of the hypersensitive reaction in tobacco by proteinaceous constituents of Pseudomonas solanacearum. Phytopathology 62, 536-542.

Weissbach, A. \& HURWITZ, J. (1959). The formation of 2-keto-3-deoxyheptonic acid in extracts of Escherichia coli B. Journal of Biological Chemistry 234, 705-709.

WeSTPHAL, O. \& JANN, K. (1965). Bacterial lipopolysaccharides. Extraction with phenol-water and further applications of the procedure. Methods in Carbohydrate Chemistry 5, 83-91.

WRIGHT, B. G. \& REBERS, R. A. (1972). Procedure for determining heptose in lipopolysaccharides. Analytical Biochemistry 49, 307-319. 